\title{
Encyclopaedic Information in Ideographic Description of Language of Institutional Relations
}

\author{
Anna Shchetinina*, and Anastasiya Blinova \\ Russian State Vocational Pedagogical University, 620098 Yekaterinburg, Russia,
}

\begin{abstract}
The issue of including encyclopedic information in the ideographic dictionary of social vocabulary is considered in the article. The relevance of the study is due to the active functioning of the vocabulary of the institutional sphere in the modern information environment. It is noted that modern explanatory dictionaries do not provide sufficient information about the nominations of realities from the political and social spheres. Thus, lexicographical sources do not include or fragmentarily include language units that fix the original (single) historical or cultural realities. It is argued that the absence of such nominations violates the systemic nature of the representation of lexical sets that represent fragments of social reality. It is noted that the ideographic description of social vocabulary in the dictionary by means of the method of ideographic reconstruction of nominative sets allows one to represent those language units (lexemes, phraseological units, nonidiomatic compound expressions) that call facts of reality important for a person, society or state. Such facts include, among other things, proper names, the fixation of which in the dictionary is interesting from the point of view of the linguistic-creative nomination of historical phenomena, events, personalities and is necessary for the full description of social vocabulary. It is noted that language units that call historical and cultural facts can be extracted from different idioms (literary language, dialects, jargon, urban vernacular), as well as from historical and modern dictionaries. It is concluded that the description of social vocabulary, differentiated from the point of view of stylistics and time of use, will create a more objective picture of the institutional interaction of people in different periods of history.
\end{abstract}

\section{Introduction}

The ideographic description of the social vocabulary in the dictionary allows one, with the help of the method of ideographic reconstruction of nominative sets, to present those linguistic units that call the facts of reality important for a person, a group of people or a society as a whole. By social vocabulary we mean the aggregate of linguistic units: lexemes, phraseological units, compound non-idiomatic expressions, and also paremias (since they are sufficiently stable facts of speech) - in the meanings of which social semes are identified, that is, the semantic components that objectify the belonging of the nominated object, its properties or actions to the sphere of institutional communication ('state', 'power', 'society', 'job position', etc.) or social non-institutional interaction. Extraction and systematization according to the ideographic principle of lexemes, phraseological units, non-idiomatic compound expressions and paremias from sources that represent the vocabulary of different linguistic idioms (Russian folk dialects, jargons, literary language) allow us to find out how certain phenomena, events, attitudes, values, etc. are understood by different members of the society. At the same time, for complex research and description of lexical sets with social semantics it is important to understand how these or other facts of reality are represented not only at the present stage of language development, but throughout the history of its existence. Consequently, the identification of linguistic units, differentiated from the point of view of style and time of use, makes it possible to create an objective description of the social vocabulary of the Russian language in an ideographic manner.

In modern semantics studies, different groups of lexical units are described, reflecting ideas about social groups, human characteristics, institutional relationships, etc. in different types of idioms and discourses, for example, in the works of L. V. Balashova [1], M. L. Kusova [2], T. V. Leontyeva [3], A. Musolfa [4], A. M. Plotnikova [5], A. V. Shchetinina [6], etc., but there is as yet no comprehensive description of social vocabulary. Therefore, the research team (the author of this article is one of its members), working on the grant "Russian society in the mirror of lexical semantics", develops a methodology for identifying and describing nominations, the values of which contain social semes. One of the methodological issues arising in the process of research is related to the definition of the circle of linguistic facts that can be included in the lexicographical description of

* Corresponding author: anna.shhetinina@rsvpu.ru 
social vocabulary. In particular, the researchers of social vocabulary are facing the problem of identifying and describing language units (lexemes, phraseological units, non-idiomatic compound expressions) that are designations of historical facts (events, phenomena, personalities, documents, etc. that actually took place) and are usually presented in encyclopedic sources.

As you know, traditionally defining dictionary (including explanatory and ideographic ones) rarely include proper names, which act as symbolic signs in the domestic, foreign or world culture, since the respective persons had wide popularity and influence in a certain historical period. Anthroponyms and toponyms are usually fixed by special linguistic dictionaries (see e.g. [7], [8], [9], etc.), historical facts encyclopedic (e.g., [10]) or branch (e.g., [11]) dictionaries. However, in our opinion, the exclusion of the vocabulary of the institutional relations of linguistic units fixing original (isolated) historical or cultural realities from the complex description violates the systemic nature of lexical sets representation that express fragments of social reality.

\section{Reflection of historical facts in the ideographic dictionary}

In the process of drawing up the ideology of social vocabulary representing relations in the institutional sphere, a number of nominative sets, represented by both nominal and proper names, are revealed, which are interesting from the point of view of the linguisticcreative nomination of historical facts. So, for example, phraseological expressions and non-idiomatic combinations with social semantics, formed by secondary nomination (медный бунт [Copper Kevolt], оранжевая революиия [Orange Revolution], Кровавое воскресенье [Bloody Sunday], Золотая Орда [Golden Horde], etc.) are of interest from the point of view of the semantic motivation of their meanings, revealing the mechanism of formation of these word combinations. At the same time, these linguistic units report information on historical events, personalities, geographical realities, etc., that is, they represent encyclopedic information.

Lexems that denote historical facts can motivate the formation of other linguistic units with social semes in meanings. For example: the word opдa [horde] is a polysemant [12: 662]: the first meaning, it is 'hist. the name of the major Turkic and Mongolian feudal states in the Middle Ages, as well as the base, the whereabouts of their rulers', the second -'neglect. enemy troops; regiment', the third, 'colloq. crowded, disorderly and noisy crowd, a gathering of someone'. All three lexemes have social components in the meanings (1: 'feudal', 'state', 'base', 'ruler', 2: 'troops', 'regiment', 'enemy', 3: 'crowd') and are included in nominative sets, representing different ideograms accordingly: "historical state", "enemy troops", "crowd, gathering". At the same time, the first meaning of the word, ордa [horde] is a terminological historicism; it fixes encyclopaedic information and causes the appearance of other designations of historical states including the horde component. Thus, the "Dictionary of the Russian language of the 11th-17th centuries" in the dictionary article devoted to the word horde fixes, firstly, the general significance ('the name of the major Turkic and Mongolian feudal states and unions of nomadic tribes, primarily the Golden Horde state (XIII-XV centuries)' [13: 64]). Secondly, in the same dictionary article, the names of different states with a component of the opda [horde] are specified: Большая (Великая) Орда [Great Horde], Золотая Орда [Golden Horde], Казакская (Казаиккая, Казачья) Орда [Kazak (Cossack) Horde], Нагайская Орда [Nagay Horde]. Each of them is supplied with a dictionary definition, including encyclopedic information (dates, area) and illustrative material, for example:

Большая (Великая) Орда 'татарское феодальное государство (XV-XVI вв.) в низовьях Волги, возникшее в процессе распада Золотоордынского государства': Вселишася в Болшой Орде нагаи и мангиты из-за Яика пришедше. ХVI в. Крымьский ицарь Минъ-Гирбй побиль Ахмата чиря Большия Opdbl. XVI-XVII вв. 1560 г. [Great Horde 'tatar feudal state (XV-XVI centuries) in the lower reaches of the Volga, which arose in the process of the collapse of the Golden Horde state': All in the Great Horde nagay and the mangitas came from behind Yaik. XVI century the Crimean Khanate Ming-Giray defeated Akhmat king of the Great Horde. XVI-XVII centuries. 1560] [13: 64].

The identification of linguistic facts (including their own names), which call the realities of the present or the historical past, and their inclusion in an ideographic description, allow us to create a more complete picture of reality. And vice versa, their mechanical exclusion from the ideographic description creates certain semantic lacunae and violates the logic of the systematization of social vocabulary. Here is the illustration of this statement. The lexico-semantic set "Institutional relations" includes a number of subsets, among which a group that unites three ideograms that are in a relationship of semantic dependence (in the logic of sequential inclusion) is singled out:

\section{NOUN "state" NOUN "a state with a certain form of government" \\ NOUN "a historical state with a definite form of government"}

The ideogram "state" unites lexical representatives on the basis of the commonality of the semes ('state', 'country', 'system of governance'), which are in the assertive zone. Differential semes ('monarchical', 'feudal', 'capitalist' 'defeated', 'dependent', 'led by the sultan', etc.) are in the pericentric zone of meaning and allow us to identify types of states. In this case, differential semes located on the far periphery (for example, revealed in the illustrative material) in the meanings of a number of words determine the allocation of one more ideogram "historical state". The name can be considered conditional, since the seme 'historical' is potential, it does not enter into the meanings of words 
that call specific states, but imply the reality of their existence in the past or present.

Let us illustrate the relationship between the above ideogram and their lexical representatives. Thus, the lexeme of the empire ("the monarchic state, headed by the emperor' [12: 662]) represents the ideogram "a state with a definite form of government" and at the same time the generic seme 'empire' is revealed in the meanings of words and phrases denoting "a historical state with a definite form of government": Российская империя [the Russian Empire], Российская корона [the Russian Crown], рейx [the Reich], Поднебесная [the Celestial Empire], etc. (note that these language units are not represented in the dictionary [12], their meaning is extracted from encyclopedic dictionaries or contexts).

\section{For example:}

РЕ́ЙХ. Любая из империй немцев или Германии: «Священная Римская империя»; Второй рейх, возглавляемый прусской династией Гогенцоллеров (1871-1918); Третий рейх в нацистской Германии (1933-1945) [14: 1114].

- «Необходимость даже и в нормальные времена, - заявил рейхсканцлер, двадцать раз в течение четырех лет посылать народ к урнам, то в рейхе, то в отдельных землях, - приводит к полному падению авторитета законодательных собраний в глазах народа» (Н. Устрялов. Германский национал-социализм, 1933).

- Во всем габсбургском рейхе он один смел бросить в лицо императору слово правды (Е. Парнов. Александрийская гемма, 1990).

[REICH. Any of the empires of the Germans or Germany: "Holy Roman Empire"; The Second Reich, led by the Prussian dynasty of the Hohenzollers (1871-1918); The Third Reich in Nazi Germany (1933-1945) [14: 1114].

"The necessity even in normal times, the Reich Chancellor declared, sending the people twenty times within four years to the ballot boxes, either in the Reich, or in separate lands, leads to a complete drop in the authority of the legislative assemblies in the eyes of the people" (N. Ustryalov. German National Socialism, 1933).

- In the whole of the Habsburg Reich, he alone dared to throw the word of truth in the face of the emperor (E. Parnov, Alexandrian Gemma, 1990)] [15] ${ }^{\mathrm{a}}$.

The generic sema 'empire' is supplemented by differential semes 'Germans', 'Sacred Roman', 'Prussian dynasty', 'Hohenzollers', 'Nazi Germany', which are markers of a separate epoch, which causes the inclusion of the Reich lexeme in a special group of linguistic units with the meaning "historical state".

\footnotetext{
${ }^{a}$ A dictionary entry from the developing dictionary of social vocabulary.
}

Representatives of the ideogram "a historical state with a certain form of government" are both lexemes and phraseological expressions from different linguistic idioms:

(1) literary language:

- words and phrases of a terminological nature: peŭx [Reich], метрополия [metropolis], доминион [dominion]; Первый рейх [First Reich], Второй рейх [Second Reich], Третий рейх [Third Reich]; Большая (Великая) Орда [Great Horde], Золотая орда [Golden Horde], Нагайская орда [Nagay Horde]; Российская империя [The Russian], and others;

- phraseological expressions predominantly from publicistic and artistic speech: туманный Альбион 'древнее описательное наименование Британии' [foggy Albion 'the ancient descriptive name of Britain'] [16: 21-22]); весёлая Англия 'устар. об Англии, Великобритании' [merry England 'obsolete, about England, Great Britain'] [16: 24-25]); владычица морей 'публ. торж. перифрастическое название Британии' [the mistress of the seas 'public. formal, the periphrastic name of Britain'] [16: 101]), добрая старая Англия 'об Англии, Великобритании' [good old England 'about England, Britain'] [16:25]).

It is interesting that phraseological units that call England are represented in phraseological dictionaries, for example, A. K. Birikh "Russian phraseology. Historical and etymological dictionary" (2005) [16], and the periphrastic names of other states in lexicographic sources were not found. It is quite obvious that they are actively used in artistic and public speech. For example, we have identified stable expressions (each in more than one hundred contexts recorded both in the National Corpus of the Russian language and elsewhere):

- страна фараонов [the country of the pharaohs (Egypt)]: Ситуация в стране фараонов патовая: уличными боями охвачена Александрия, где противоборствующие бомбят друг друга коктейлями Молотова (И. Юрченко. Египет в огне... // Комсомольская правда, 2013.07.06) [The situation in the country of the pharaohs is in a bind: Alexandria is enveloped by street battles, where the warring parties bombard each other with Molotov cocktails (I. Yurchenko. Egypt is on fire... // Komsomolskaya Pravda, 2013.07.06)] [15];

- страна восходящего солнща [the country of the rising sun (Japan)]: У Японии уже есть противоракетные комплексы SM-3, которые установлены на кораблях ВMC Страны восходящцего солнца, и наземные комплексы Patriot PAC-3 (Г. Иванов. Москва или Пхеньян? // Аргументы и факты, 20.12.2017) [Japan already has anti-missile systems SM-3, which are installed on the ships of the Naval forces of the Land of the Rising Sun, and ground-based systems Patriot PAC-3 (G. Ivanov. Moscow or Pyongyang? // Arguments and facts, 20.12.2017)] [17];

- страна тюльпанов [the country of the tulips (Holland)]: Европейский ордер на арест Измаилова был разослан прокуратурой Нидерландов по европейским столицам еще несколько месяцев тому 
назад после того, как стали выплывать на поверхность детали этого потрясшего Страну тюльпанов преступления (В. Прокофьев. Сценаристы из Чечни // Труд-7, 2005.06.16) [The European warrant for Izmailov's arrest was sent out by the Dutch prosecutor's office in European capitals a few months ago after the details of this crime which shocked the country of the Tulips began to surface (V. Prokofiev, Scenarists from Chechnya // Trud-7, 2005.06.16)] [15];

- Поднебесная [the Celestial Empire (China)]: По доле в мировой торговле Поднебесная опередила Страну восходящего солниа, которая в 60-80-х годах совериила экономическое чудо, заполонив весь мир своими автомашинами и телевизорами (В. Овчинников. Размышления странника, 2012) [Ву the share in world trade, the Celestial Empire outstripped the Land of the Rising Sun, which in the 1960s and 1980s made an economic miracle, flooding the whole world with its cars and TVs (V. Ovchinnikov, Wanderer's Reflections, 2012)] [15], and others.

(2) nonliterary language:

- jargon, fixed in dictionaries, and also unrecorded, since they have appeared in the last decades, deserve, in our opinion, inclusion in social ideography, because, firstly, they reflect, as a rule, the emotional attitude of different social groups to the state, and secondly, they have a high frequency of usage. Thus, in the dictionaries of slang the words that call the Soviet Union are recorded: совдепия [sovdepia], совдеn [sovdep], совок [sovok]; in Internet communication, modern Russia is called называют рашка [rashka], раша [rasha], наша Раша [nash Rasha]; America - Пендосия [Pendosia] (even there is a site Pindosiya.com, positioning itself as an Internet platform "for productive communication ... for young people and people with an active life position", "establishing business of Russians from America and Russia", etc.) [18]; Modern Ukraine Незалежная [Nezalezhnaya], Укропия [Ukropia], etc.

Thus, the inclusion in the ideographic description of the vocabulary of institutional relations between the names of existing or existed states, including those, complete picture of the fragment of reality connected with the attitude of people to the state.

\section{Conclusion}

The presentation of social vocabulary on a logicalconceptual basis by means of systematization of nominative sets through the development of ideograms makes it possible to carry out a linguistic reconstruction of a person's knowledge of the world around him. The circle of linguistic facts reflecting institutional relations includes not only the nominations of common concepts (бунт [revolt], револючия [revolution], империя [empire], руководство [leadership]), but also linguistic units that denote historically and culturally significant original phenomena, events, persons (соляной бунт [Salt Revolt], револючия роз [Rose Revolution], Поднебесная [Celestial Empire], Вашингтонский обком [Washington Regional Committee], Горби
[Gorby]). As the study has shown, there is no system in lexicography of proper names and units of intermediate status: they are either not represented in dictionaries at all, or are presented in fragmentary form. At the same time, in our opinion, the systematic representation in the ideology of social vocabulary of phraseological units, non-idiomatic compound expressions, lexemes calling original facts of history, will allow us to more objectively present the institutional sphere of life in retrospective and modern coverage. In addition, it is possible to say that this ethno-cultural information can be used in the practice of studying the Russian language as a non-native, as well as comparative study of languages (see about this [19]).

The study is supported by the Russian Science Foundation (project No. 16-18-02075 "Russian Society in the Mirror of Lexical Semantics").

\section{Abbreviations}

hist. - historical

colloq. - colloquial

neglect. - neglective

publ. - public

form. - formal

\section{References}

1. L.V. Balashova, Political linguistics 20, 21-43 (2006)

2. M. L. Kusova, Representation of society and social problems to the lexical picture of the world, VERBUM: language, text, dictionary: collection of scientific papers: is dedicated to the jubilee of L. G. Babenko (Publishing house of Ural. Univ., Ekaterinburg, 2006)

3. T. V. Leontyeva, Vocabulary of social regulation in Russian folk dialects (Publishing house Ros. state. prof.-ped. University, Ekaterinburg, 2013)

4. A. Musolff, Metaphor and Political Discourse. Analogical Reasoning in Debates about Europe (Palgrave Macmillan, Basingstoke, 2004)

5. A. M. Plotnikova, Problems of history, philology, culture 3, 22-24 (2014)

6. A. V. Schetinina, Scientific dialogue 11, 214-230 (2017)

7. N. M. Tupikov, Dictionary of Old Russian Names (St. Petersburg, 1903)

8. I. M. Ganzhina, Dictionary of Modern Russian Surnames (Moscow, 2001)

9. G. P. Smolitskaya, Toponymic Dictionary of Central Russia (Armada Press, Moscow, 2002)

10. Great illustrated encyclopedia (AST: Astrel, Moscow, 2010)

11. N. Georgieva, V. Georgiev, A. Orlov, Historical Dictionary (Prospekt Publishing House, Moscow, 2018) 
12. Dictionary of the Russian language 1, (Poligrafresursy, Moscow, 1999)

13. Dictionary of Russian language of XI-XVII centuries 13, (Science, Moscow, 1982)

14. World encyclopedic dictionary (The Modern literati, Minsk, 2004)

15. Russian National Corpus, URL: www.ruscorpora.ru. (date of access: 20.05.2018). (in Russian)

16. A. K. Birikh, V. M. Mokienko, L. I. Stepanova, Russian phraseology. Historical and etymological dictionary (Astrel: AST: The Guardian, Moscow, 1996)

17. Archive of authors

18. Pindosiya.com, URL: http://pindosiya.com/. (date of access: 20.05.2018)

19. T. Leontyeva, E. Dorozhkin, A. Shchetinina, Kh. Tabarov, XLinguae Journal 9(4), 100-107 (2016) 